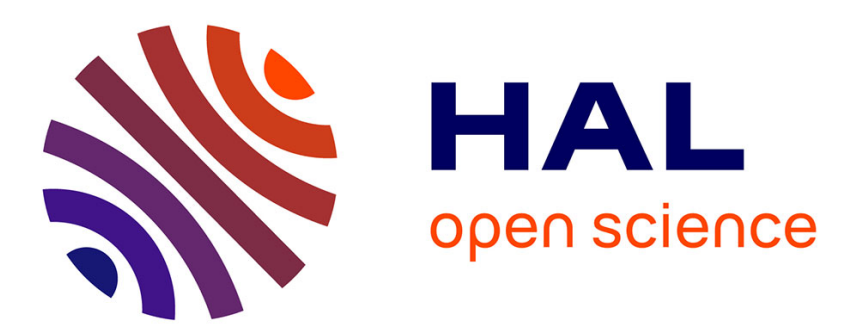

\title{
The contrasted structural and magnetic behaviour of two single-component paramagnetic dithiolene complexes
}

\author{
Mitsushiro Nomura, Marc Fourmigué
}

\section{To cite this version:}

Mitsushiro Nomura, Marc Fourmigué. The contrasted structural and magnetic behaviour of two single-component paramagnetic dithiolene complexes. New Journal of Chemistry, 2007, 31, pp.528534. 10.1039/b700278e . hal-00191005

\section{HAL Id: hal-00191005 \\ https://hal.science/hal-00191005}

Submitted on 23 Aug 2013

HAL is a multi-disciplinary open access archive for the deposit and dissemination of scientific research documents, whether they are published or not. The documents may come from teaching and research institutions in France or abroad, or from public or private research centers.
L'archive ouverte pluridisciplinaire HAL, est destinée au dépôt et à la diffusion de documents scientifiques de niveau recherche, publiés ou non, émanant des établissements d'enseignement et de recherche français ou étrangers, des laboratoires publics ou privés. 


\title{
The contrasted structural and magnetic behaviour of two single-component paramagnetic dithiolene complexes
}

\author{
Mitsushiro Nomura and Marc Fourmigué* \\ Received (in Montpellier, France) 9th January 2007, Accepted 22nd February 2007 \\ First published as an Advance Article on the web 19th March 2007 \\ DOI: $10.1039 / b 700278 \mathrm{e}$
}

The neutral organometallic/dithiolene radical complexes [CpNi(oxddt)] and [CpNi(bddt)] were prepared, respectively, from the reactions of $\left[\mathrm{Ni}(\text { oxddt })_{2}\right]$ with $\left[\mathrm{Cp}_{2} \mathrm{Ni}\right]$ and $\left(\mathrm{NBu}_{4}\right)\left[\mathrm{Ni}(\text { bddt })_{2}\right]$ with $[\mathrm{CpNi}(\mathrm{cod})]\left(\mathrm{BF}_{4}\right)($ oxddt $=o$-xylenediyldithioethylene-1,2-dithiolato, bddt $=1,4-$

butanediyldithioethylene-1,2-dithiolato). Both complexes exhibit reversible oxidation and reduction waves to the cation and anion forms, respectively. A NIR absorption is observed around $\lambda_{\max }=825$ for [CpNi(oxddt)] and $774 \mathrm{~nm}$ for [CpNi(bddt)] in dichloromethane solution. The X-ray crystal structures of the two complexes show two-legged piano-stool geometries around the central nickel atom (formally $\mathrm{Ni}^{\mathrm{III}}$ ) and strong distortions from planarity of the eightmembered ring moieties. In the solid state, the stronger rigidity of [CpNi(oxddt)] allows for a face-to-face $\pi-\pi$ stacking of the radicals into dyads, confirmed by a singlet-triplet magnetic behaviour while the more flexible $[\mathrm{CpNi}(\mathrm{bddt})]$ radical complexes only interact through a lateral antiferromagnetic interaction giving rise to Heisenberg-type uniform spin chains.

\section{Introduction}

Metal dithiolene complexes have been extensively investigated due to their combination of functional properties, specific geometries, and intermolecular interactions that confer them an enormous interest in the field of magnetism, ${ }^{1}$ conductivities, ${ }^{2}$ and optical properties. ${ }^{3}$ The metal dithiolene complexes involve not only homoleptic types such as bis(dithiolene) $\left[\mathrm{M}(\text { dithiolene })_{2}\right]^{n-} \quad(\mathrm{M}=\mathrm{Ni}, \mathrm{Pd}, \mathrm{Pt}),{ }^{4}$ tris(dithiolene $)$ $\left.[\mathrm{M} \text { (dithiolene })_{3}\right]^{n-}(\mathrm{M}=\mathrm{V}, \mathrm{Cr}, \mathrm{Mo}, \mathrm{W}, \mathrm{Re}),{ }^{5}\left(\mathrm{Nd}, \mathrm{Ce},{ }^{6} \mathrm{U}\right)^{7}$ and tetrakis(dithiolene) $\left[\mathrm{M}(\text { dithiolene })_{4}\right]^{n-}(\mathrm{M}=\mathrm{Ce}, \mathrm{U}){ }^{7,8}$ which are composed only of dithiolene ligands, but also heteroleptic ones such as $\left[\mathrm{M}(\right.$ dithiolene $\left.) \mathrm{L}_{2}\right](\mathrm{M}=\mathrm{Ni}, \mathrm{Pd}$, $\mathrm{Pt})^{9}$ and organometallic dithiolene complexes. The latter organometallic dithiolene complexes include $\left[(\mathrm{Cp})_{n} \mathrm{M}\right.$ (dithiolene $\left.)_{n}\right]\left(\mathrm{Cp}=\eta^{5}\right.$-cyclopentadienyl $),{ }^{10}\left[\left(\eta^{6}-\mathrm{C}_{6} \mathrm{R}_{6}\right) \mathrm{M}\right.$ (dithiolene $)](M=R u)^{11}$ and $\left[\left(\eta^{4}-C_{4} R_{4}\right) M(\right.$ dithiolene $\left.)\right](M=N i$, $\mathrm{Pd}){ }^{12}$ They have electron-deficient metal centres, which are stabilized by a $\pi$-electron donation of the dithiolene ligands ${ }^{13}$ and by the $\pi$-coordinated organometallic ligand.

Different series of paramagnetic complexes such as the cationic $\mathrm{d}^{1}\left[\mathrm{Cp}_{2} \mathrm{Mo} \text { (dithiolene) }\right]^{+}$have shown a wide variety of magnetic behaviours, from uniform spin chains to spin ladders or antiferromagnetic ground states, depending strongly on the size, shape and charge of the counter ion. ${ }^{14}$ On the other hand, $\left[\mathrm{CpNi}^{\mathrm{III}} \text { (dithiolene) }\right]^{\bullet}$ complexes are paramagnetic $(S=1 / 2)$ in their neutral states. ${ }^{15}$ Namely, these species belong to a larger group of single-component magnetic dithiolene complexes such as $\left[\mathrm{Au}^{\mathrm{IV}}(\text { dithiolene })_{2}\right],{ }^{16}\left[\mathrm{CpMo}^{\mathrm{V}}\right.$ (dithiolene $\left.)_{2}\right]^{17}$ or $\left[\mathrm{CpCo}^{\mathrm{IV}}(\mathrm{Br})(\right.$ dithiolene $\left.)\right],{ }^{18}$ where strong

Sciences Chimiques de Rennes, UMR 6226 CNRS-Université de Rennes 1, Equipe MaCSE, Campus de Beaulieu, 35042 Rennes cedex, (France).E-mail: marc.fourmigue@univ-rennes1.fr; Fax: (+33) 223 236732 intermolecular interactions can develop in the solid state in the absence of any counter ions. For example, some singlecomponent radical $\left[\mathrm{CpNi}^{\mathrm{III}}\right.$ (dithiolene) $]$ complexes have shown unexpectedly strong antiferromagnetic interactions due not only to dithiolene/dithiolene contacts as anticipated but also to $\mathrm{Cp}$. C $\mathrm{Cp}$ face-to-face overlap. ${ }^{15 c}$

We have recently reported the synthesis and properties of such $\mathrm{CpNi}$ (dithiolene) complexes functionalized with, (i) a simple $\mathrm{R}$ substituent as in $\left[\mathrm{CpNi}\left(\mathrm{S}_{2} \mathrm{C}_{2} \mathrm{R}_{2}\right)\right]$ with $\mathrm{R}=\mathrm{CN}$, COOMe, $\mathrm{Ph}, \mathrm{Me},{ }^{15 b}$ (ii) sulfur-rich outer rings as in $[\mathrm{CpNi}$ $(\mathrm{dmit})](\mathrm{dmit}=1,3 \text {-dithiol-2-thione-4,5-dithiolato })^{15 a}$ and [CpNi(dddt)] (dddt = 5,6-dihydro-1,4-dithiin-2,3-dithiolato) groups, ${ }^{15 c}$ (iii) a rigid six-membered ring in [CpNi(bdt)] (bdt $=1,2$-benzenedithiolato), ${ }^{15 c, e}$ and (iv) a flexible seven-membered ring as in [CpNi(pddt)] (pddt $=1,3$-propanediyldithioethylene-1,2-dithiolato) and its analogues (Chart 1). ${ }^{15 d}$

The structural and magnetic behaviour of these complexes was shown to be highly dependent on the nature and steric constraints of the substituents on the dithiolene ligand, offering a wide variety of possible magnetic interactions (dyadic associations with singlet-triplet behaviour, alternated or

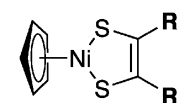

$\mathrm{CpNi}\left(\mathrm{S}_{2} \mathrm{C}_{2} \mathrm{R}_{2}\right)$ $\mathrm{R}=\mathrm{CN}$, COOMe, $\mathrm{Ph}, \mathrm{Me}$

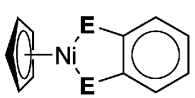

CpNi(bdt): E = S CpNi(bds): $\mathrm{E}=\mathrm{Se}$

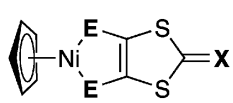

CpNi(dmit): $E=S, X=S$ CpNi(dmid): $E=S, X=O$ CpNi(dsit): $E=S e, X=S$

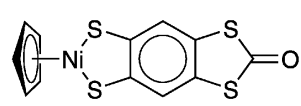

CpNi(bdtodt)

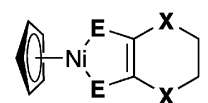

CpNi(dddt): $E=S, X=S$ CpNi(dsdt): $E=S, X=S e$ CpNi(ddds): $E=S e, X=S$

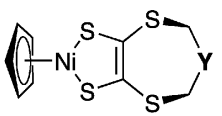

CpNi(pddt): $\mathrm{Y}=\mathrm{CH}_{2}$ $\mathrm{Y}=\mathrm{CF}_{2}, \mathrm{C}=\mathrm{CH}_{2}, \mathrm{~S}, \mathrm{C}=\mathrm{O}$ 


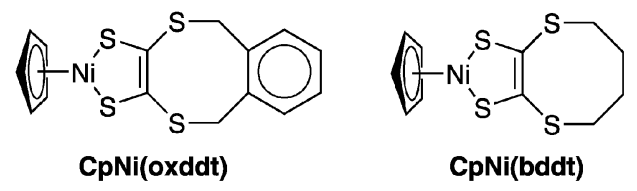

Chart 2

uniform chains through lateral S...S contacts, antiferromagnetic three-dimensional ground state), even for closely related molecular structures. In order to get a further insight in this extensive family, we have investigated two further neutral radical complexes where the metallacycle is now fused with a larger and flexible eight-membered ring, namely the [CpNi(oxddt) $\quad$ (oxddt $=o$-xylenediyldithioethylene-1,2dithiolato) and $[\mathrm{CpNi}(\mathrm{bddt})]$ (bddt $=1$,4-butanediyldithioethylene-1,2-dithiolato) complexes shown in Chart 2.

While both complexes are expected to exhibit closely related electronic structures and spin delocalisation, their structural and accordingly magnetic behaviour in the solid state might strongly depend on the shape adopted by the eight-membered outer ring. Indeed, the anticipated stronger rigidity of the $o$-xylylene derivative will contrast with the more flexible character of the 1,4-butylene one. We report here the preparation, electronic properties, X-ray crystal structures, and magnetic properties of the two complexes, showing that they are indeed characterized by completely different structural and magnetic properties, intimately related to the different ways such radical molecules manage to increase chemical bonding in the solid state, either through localized 2e bonds or through delocalized one-dimensional antiferromagnetic spin chains.

\section{Results and discussion}

\section{Syntheses and molecular structures of [CpNi(oxddt)] and} [CpNi(bddt)]

The formally $\mathrm{Ni}^{\mathrm{III}}$ species can be obtained either from the reaction of the two charged $\mathrm{Ni}^{\mathrm{III}}$ species, [Ni(dithiolene) $\left.)_{2}\right]^{-}$ and $\left[\mathrm{Cp}_{2} \mathrm{Ni}\right]^{+}$, or from the reaction of the $\mathrm{Ni}^{\mathrm{II}}\left[\mathrm{Cp}_{2} \mathrm{Ni}\right]$ with the formally $\left.\mathrm{Ni}^{\mathrm{IV}}[\mathrm{Ni} \text { (dithiolene) })_{2}\right]^{0} .^{15}$ Accordingly, the reaction of the neutral square-planar dithiolene complex $\left[\mathrm{Ni}(\text { oxddt })_{2}\right]$ with $\left[\mathrm{Cp}_{2} \mathrm{Ni}\right]$ in toluene $\left(80{ }^{\circ} \mathrm{C}\right)$ gave [CpNi(oxddt)] in 44\% yield (Scheme 1). However, the corresponding $\left[\mathrm{Ni}(\mathrm{bddt})_{2}\right]$ reacted with $\left[\mathrm{Cp}_{2} \mathrm{Ni}\right]$ to form [CpNi(bddt)] only in a low yield. On the other hand, the reaction of $\left(\mathrm{NBu}_{4}\right)\left[\mathrm{Ni}(\mathrm{bddt})_{2}\right]$ with $[\mathrm{CpNi}(\mathrm{cod})]\left(\mathrm{BF}_{4}\right)$ in refluxing methanol afforded $[\mathrm{CpNi}(\mathrm{bddt})]$ in an improved $30 \%$ yield

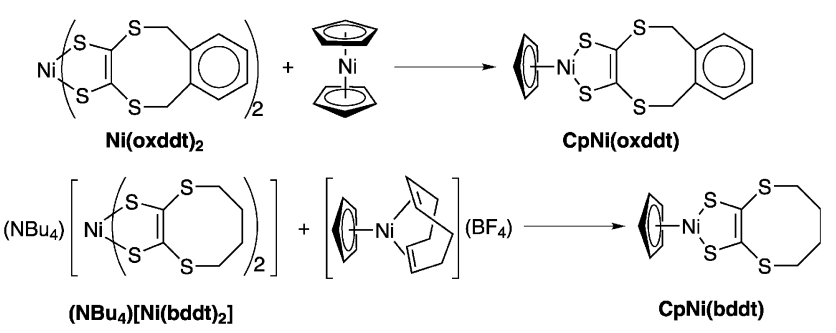

Scheme 1
(Scheme 1). This method using $[\mathrm{CpNi}(\operatorname{cod})]\left(\mathrm{BF}_{4}\right)$ as a $\mathrm{Ni}^{\mathrm{II}}$ precursor has been recently developed during the optimization of synthesis of $[\mathrm{CpNi}(\mathrm{dddt})] .{ }^{15 c}$ Conveniently, the neutral [CpNi(dithiolene)] complexes are easy to separate from these ionic components by column chromatography on silica gel. Both products are air-stable at room temperature, and are more soluble in typical organic solvents (dichloromethane, toluene, acetone and THF) than the other [CpNi(dithiolene)] complexes shown in Chart 1.

The ORTEP drawings of [CpNi(oxddt)] and [CpNi(bddt)] are shown in Fig. 1. [CpNi(oxddt)] and [CpNi(bddt)] crystallize in the triclinic ( $P \overline{1}$ space group) and monoclinic crystal systems $\left(P 2_{1} / n\right)$, respectively, with one crystallographically independent molecule in the unit cell for both compounds.

The complexes have two-legged piano-stool geometries with molecular geometries similar to the 16-electron [CpM(dithiolene $)](\mathrm{M}=\mathrm{Co}, \mathrm{Rh}, \mathrm{Ir})$ and $\left[\left(\eta^{6}-\mathrm{C}_{6} \mathrm{R}_{6}\right) \mathrm{Ru}(\right.$ dithiolene $\left.)\right]$ complexes. Selected bond lengths $(\AA)$, bond angles and dihedral angles $\left({ }^{\circ}\right)$ are summarized in Tables 1 and 2, respectively. The $\mathrm{Ni}-\mathrm{S}$ bond lengths in [CpNi(oxddt)] and [CpNi(bddt)] are $c a$. $2.13 \AA$ and these lengths are slightly longer than in other [CpNi(dithiolene)] complexes ( $c a \cdot 2.12 \AA$ ) except for [CpNi (dmit)] (Ni-S $2.13 \AA$ ). In general, the $\mathrm{Ni}-\mathrm{S}$ lengths in [CpNi (dithiolene)] are longer than the $\mathrm{Co}-\mathrm{S}$ lengths in $[\mathrm{CpCo}$ (dithiolene)] complexes $(2.10-2.11 \AA) .{ }^{10,19}$ This result suggests different $\pi$-electron donating effect from sulfur to metal ${ }^{13}$ in the $\mathrm{Ni}$ and $\mathrm{Co}$ dithiolene rings, namely, the difference between 17-electron $\left(\mathrm{Ni}^{\mathrm{III}}\right)$ and 16-electron $\left(\mathrm{Co}^{\mathrm{III}}\right)$ dithiolene complexes. Furthermore, in the comparison of [CpNi(bddt)] with the corresponding square-planar $\mathrm{Ni}$ dithiolene complex $\left(\mathrm{NEt}_{4}\right)\left[\mathrm{Ni}(\mathrm{bddt})_{2}\right]$ (Table 1), the $\mathrm{Ni}-\mathrm{S}$ length in [CpNi(bddt)] is slightly shorter than that of $\left(\mathrm{NEt}_{4}\right)\left[\mathrm{Ni}(\mathrm{bddt})_{2}\right](\mathrm{Ni}-\mathrm{S} 2.15$ A). ${ }^{20}$ Similar tendencies have been observed between $[\mathrm{CpNi}(\mathrm{pddt})]$ and $\left[\mathrm{Ni}(\mathrm{pddt})_{2}\right]$ monoanion series. ${ }^{15 d, 21}$

In fact, the dihedral angles $\left(\theta_{1}\right)$ between the $\mathrm{Cp}$ and $\mathrm{NiS}_{2}$ mean planes are almost $90^{\circ}$ (Fig. 1 and Table 2). The fivemembered nickeladithiolene plane $\left(\mathrm{NiS}_{2} \mathrm{C}_{2}\right)$ is quite planar. This plane is folded along the $\mathrm{S} \cdots \mathrm{S}$ hinge making the $\theta_{2}$ angle (Fig. 1 and Table 2). The $\theta_{2}$ values in [CpNi(oxddt)] and $[\mathrm{CpNi}$ (bddt) $]$ are 8.78 and $4.54^{\circ}$, respectively. The $\theta_{3}$ angle in Fig. 1 is the large folding of eight-membered ring moiety along the $\mathrm{S} \cdots \mathrm{S}$ hinge. The $\theta_{3}$ values of $[\mathrm{CpNi}$ (oxddt)] and [CpNi(bddt)] are 64.42 and $77.69^{\circ}$. These values are much larger than the $\theta_{3}$ values of the [CpNi(dithiolene)] complexes with a seven-membered ring $\left(\theta_{3}=61-67^{\circ}\right) .{ }^{15 d}$ Probably, the eight-membered ring moiety is significantly distorted by the flexibility of the terminal butylene group.

\section{Electronic properties}

The cyclic voltammograms (CV) of [CpNi(oxddt)] and $[\mathrm{CpNi}(\mathrm{bddt})]$ showed well-defined reversible reduction waves at -1.07 and $-1.04 \mathrm{~V}\left(v s . \mathrm{Fc} / \mathrm{Fc}^{+}\right.$), and reversible oxidation waves at 0.16 and $0.14 \mathrm{~V}$, respectively (Table 3 ).

The reduction potentials are essentially similar to those of $[\mathrm{CpNi}(\mathrm{dddt})](-1.06 \mathrm{~V})$ and $[\mathrm{CpNi}(\mathrm{pddt})](-1.08 \mathrm{~V})$. On the other hand, the oxidation potentials are slightly more anodic than those of the corresponding six-membered [CpNi(dddt)] $(-0.02 \mathrm{~V})$ and seven-membered $[\mathrm{CpNi}(\mathrm{pddt})](+0.07 \mathrm{~V})$ 

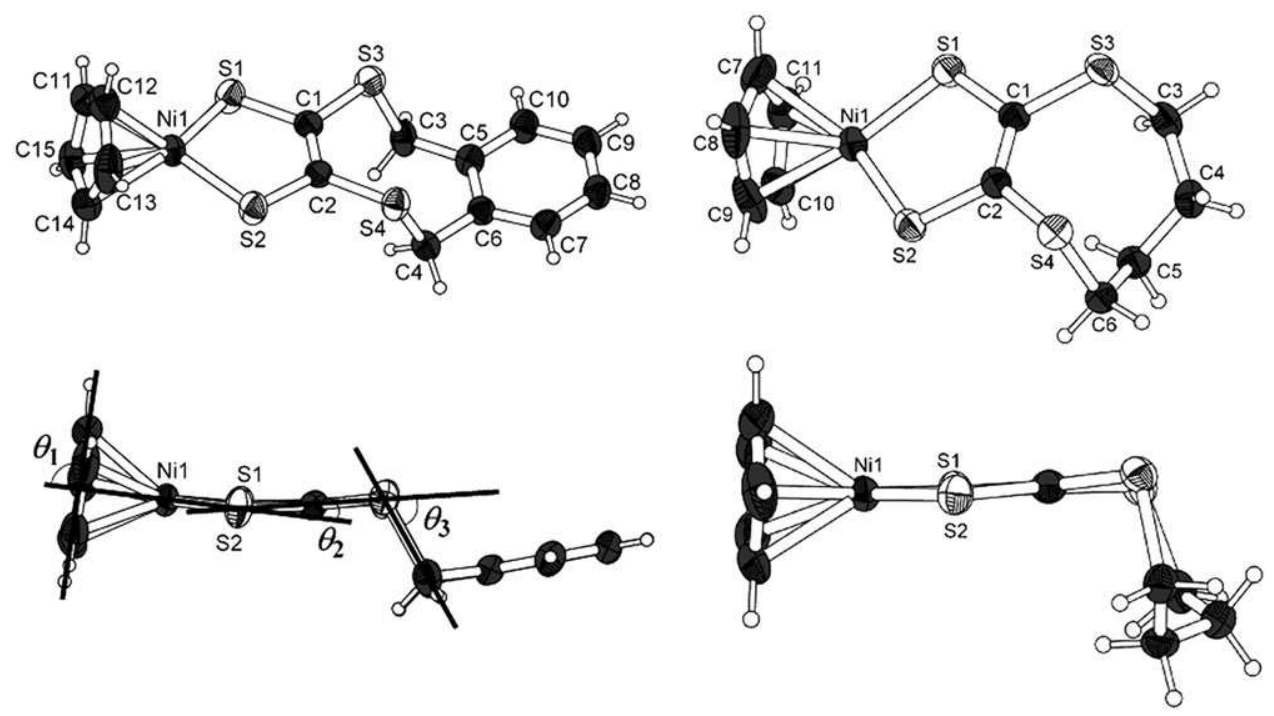

Fig. 1 The ORTEP drawings of [CpNi(oxddt)] and [CpNi(bddt)] with thermal ellipsoids drawn at 50\% probability level: (top left) [CpNi(oxddt)] showing all the atoms, (bottom left) a side view showing the definition of the three folding angles $\theta_{1-3}$ reported in Table $2 ; \theta_{1}$ is the dihedral angle $\left({ }^{\circ}\right.$ ) between the $\mathrm{Cp}$ and $\mathrm{NiS}_{2}$ mean planes, $\theta_{2}$ represents the small folding of the metallacycle along the $\mathrm{S} \cdots \mathrm{S}$ hinge, and $\theta_{3}$ is the large folding of the seven-membered ring along the $\mathrm{S} \cdots \mathrm{S}$ hinge, (top right and bottom right) [CpNi(bddt)].

Table 1 Selected bond lengths $(\AA)$ in $[\mathrm{CpNi}($ oxddt $)]$, [CpNibddt)] and reference complexes

\begin{tabular}{|c|c|c|c|c|c|c|}
\hline & Ni1-S1 & Ni1-S2 & $\mathrm{S} 1-\mathrm{C} 1$ & $\mathrm{~S} 2-\mathrm{C} 2$ & $\mathrm{C} 1-\mathrm{C} 2$ & Ref. \\
\hline$[\mathrm{CpNi}(o x d d t)]$ & $2.133(3)$ & $2.121(3)$ & $1.734(9)$ & $1.720(8)$ & $1.353(13)$ & This work \\
\hline [CpNi(bddt)] & $2.1320(18)$ & $2.1255(16)$ & $1.738(5)$ & $1.739(6)$ & $1.337(7)$ & This work \\
\hline$\left(\mathrm{NEt}_{4}\right)\left[\mathrm{Ni}(\mathrm{bddt})_{2}\right]$ & $2.148(4)$ & $2.156(3)$ & $1.690(13)$ & $1.748(13)$ & $1.368(18)$ & 20 \\
\hline$[\mathrm{CpNi}(\mathrm{pddt})]$ & $2.1242(10)$ & $2.1242(10)$ & $1.725(3)$ & $1.726(3)$ & $1.358(5)$ & $15 d$ \\
\hline [CpNi(dddt)] & $2.125(2)$ & $2.127(2)$ & $1.711(10)$ & $1.744(9)$ & $1.336(13)$ & $15 c$ \\
\hline$[\mathrm{CpNi}(\mathrm{bdt})]$ & $2.1205(13)$ & $2.1280(13)$ & $1.731(5)$ & $1.740(4)$ & $1.410(6)$ & $15 c$ \\
\hline [CpNi(dmit)] & $2.138(2)$ & $2.133(2)$ & $1.706(8)$ & $1.716(7)$ & $1.36(1)$ & $15 a$ \\
\hline$[\mathrm{CpNi}(\mathrm{mnt})]$ & $2.1255(8)$ & $2.1282(8)$ & $1.715(3)$ & $1.725(3)$ & $1.354(4)$ & $15 b$ \\
\hline
\end{tabular}

Table 2 Selected bond angles $\left({ }^{\circ}\right)$ in $[\mathrm{CpNi}($ oxddt $\left.)],[\mathrm{CpNibddt})\right]$ and reference complexes ${ }^{a}$

\begin{tabular}{|c|c|c|c|c|c|c|c|}
\hline & S1-Ni1-S2 & $\mathrm{Ni}-\mathrm{S} 1-\mathrm{C} 1$ & Ni1-S2-C2 & $\theta_{1}$ & $\theta_{2}$ & $\theta_{3}$ & Ref. \\
\hline [CpNi(oxddt)] & $91.66(10)$ & $103.9(3)$ & $105.0(3)$ & 87.37 & 8.78 & 64.42 & This work \\
\hline [CpNi(bddt)] & $92.34(6)$ & $103.7(2)$ & $103.90(19)$ & 88.87 & 4.54 & 77.69 & This work \\
\hline$\left(\mathrm{NEt}_{4}\right)\left[\mathrm{Ni}(\mathrm{bddt})_{2}\right]$ & $91.5(1)$ & $104.9(5)$ & $103.9(4)$ & - & - & - & 20 \\
\hline$[\mathrm{CpNi}(\mathrm{pddt})]$ & $92.42(4)$ & $103.97(11)$ & $103.85(11)$ & 89.3 & 7.7 & 61.32 & $15 d$ \\
\hline$[\mathrm{CpNi}(\mathrm{dddt})]$ & $92.42(9)$ & $103.4(3)$ & 103.7(3) & 86.9 & $1.0,4.3$ & - & $15 d$ \\
\hline$[\mathrm{CpNi}(\mathrm{bdt})]$ & $93.93(5)$ & $103.71(15)$ & $103.61(15)$ & 84.9 & $2.7,5.0$ & - & $15 c$ \\
\hline$[\mathrm{CpNi}(\mathrm{dmit})]$ & $94.97(8)$ & $100.8(3)$ & $100.9(3)$ & 86.5 & 4.0 & - & $15 c$ \\
\hline$[\mathrm{CpNi}(\mathrm{mnt})]$ & $94.61(3)$ & 101.7(1) & $101.7(1)$ & 89.9 & 1.4 & - & $15 a$ \\
\hline
\end{tabular}

complexes. Generally, we have observed that the nature of the dithiolene ligand strongly affects their oxidation potentials. For example, in the $[\mathrm{CpNi}(\mathrm{pddt})]$ complexes and analogs (Chart 1), the terminal $\mathrm{Y}$ groups $\left(\mathrm{Y}=\mathrm{CH}_{2}, \mathrm{CF}_{2}, \mathrm{C}=\mathrm{CH}_{2}\right.$, $\mathrm{S}, \mathrm{C}=\mathrm{O}$ ) in the seven-membered ring strongly shift their oxidation potentials to anodic potentials in the following order: $\mathrm{CF}_{2}>\mathrm{C}=\mathrm{O}>\mathrm{S}>\mathrm{C}=\mathrm{CH}_{2}>\mathrm{CH}_{2} \cdot{ }^{15 d}$ Furthermore, in the comparison of [CpNi(dddt)] and [CpNi(bdt)], there is a large difference of oxidation potential $(-0.02$ and $+0.30 \mathrm{~V})$ despite their similar reduction potentials (Table 3 ). It therefore appears that the flexibility introduced by the eight-membered rings in $[\mathrm{CpNi}($ oxddt $)]$ and $[\mathrm{CpNi}$ (bddt)] probably controls the way the two sulfur atoms of these rings contribute to the frontier orbitals, by modifying the relative orientation of the sulfur lone pairs relative to the $\mathrm{NiS}_{2} \mathrm{C}_{2}$ metallacycle mean plane.

The UV-Vis-NIR spectra of [CpNi(oxddt)] and [CpNi(bddt)] are displayed in Fig. 2 and the spectral data $\left(\lambda_{\max }\right)$ are summarized in Table 4. [CpNi(oxddt)] and [CpNi(bddt)] exhibit absorption maxima at 825 and $774 \mathrm{~nm}$ 
Table 3 Redox potentials of [CpNi(oxddt)], [CpNibddt)] and reference complexes

\begin{tabular}{|c|c|c|c|c|c|c|c|}
\hline & $E_{1 / 2}(\mathrm{red}) / \mathrm{V}\left(v s . \mathrm{Fc} / \mathrm{Fc}^{+}\right)$ & $\Delta E / \mathrm{mV}$ & $\Delta E_{\mathrm{p}} / \mathrm{mV}$ & $E_{1 / 2}(\mathrm{ox}) / \mathrm{V}\left(v s . \mathrm{Fc} / \mathrm{Fc}^{+}\right)$ & $\Delta E / \mathrm{mV}$ & $\Delta E_{\mathrm{p}} / \mathrm{mV}$ & Ref. \\
\hline [CpNi(oxddt)] & -1.07 & 68 & 94 & +0.16 & 68 & 94 & This work \\
\hline [CpNi(bddt)] & -1.04 & 62 & 65 & +0.14 & 62 & 60 & This work \\
\hline$\left[\mathrm{CpNi}\left(\mathrm{S}_{2} \mathrm{C}_{2} \mathrm{~S}_{2}\left(\mathrm{CH}_{2}\right)_{3}\right)\right]$ & -1.08 & 70 & 100 & +0.07 & 68 & 92 & $15 d$ \\
\hline$\left[\mathrm{CpNi}\left(\mathrm{S}_{2} \mathrm{C}_{2} \mathrm{~S}_{2}\left(\mathrm{CH}_{2}\right)_{2}(\mathrm{~S})\right)\right]$ & -1.02 & 70 & 98 & +0.19 & 72 & 98 & $15 d$ \\
\hline$\left[\mathrm{CpNi}\left(\mathrm{S}_{2} \mathrm{C}_{2} \mathrm{~S}_{2}\left(\mathrm{CH}_{2}\right)_{2}\left(\mathrm{CF}_{2}\right)\right)\right]$ & -0.98 & 72 & 102 & +0.25 & 72 & 98 & $15 d$ \\
\hline$\left[\mathrm{CpNi}\left(\mathrm{S}_{2} \mathrm{C}_{2} \mathrm{~S}_{2}\left(\mathrm{CH}_{2}\right)_{2}\left(\mathrm{C}=\mathrm{CH}_{2}\right)\right)\right]$ & -1.05 & 72 & 100 & +0.12 & 72 & 100 & $15 d$ \\
\hline$\left[\mathrm{CpNi}\left(\mathrm{S}_{2} \mathrm{C}_{2} \mathrm{~S}_{2}\left(\mathrm{CH}_{2}\right)_{2}(\mathrm{C}=\mathrm{O})\right)\right]$ & -0.98 & 68 & 104 & +0.22 & 68 & 98 & $15 d$ \\
\hline$[\mathrm{CpNi}(\mathrm{dddt})]$ & -1.06 & 72 & 106 & -0.02 & 74 & 106 & $15 \mathrm{c}$ \\
\hline$[\mathrm{CpNi}(\mathrm{bdt})]$ & -1.00 & 68 & 92 & +0.30 & 72 & 88 & $15 c$ \\
\hline \multicolumn{8}{|c|}{$E_{1 / 2}=\left(E_{\mathrm{p}}+E_{\mathrm{p} / 2}\right) / 2, \Delta E=\left|E_{\mathrm{p}}-E_{\mathrm{p} / 2}\right|, \Delta E_{\mathrm{p}}=\left|E_{\mathrm{pa}}-E_{\mathrm{pc}}\right|}$. \\
\hline
\end{tabular}

in dichloromethane, respectively. The absorption maximum of [CpNi(oxddt)] is as for [CpNi(dithiolene)] complexes with a seven-membered ring (798-848 $\mathrm{nm})$. On the other hand, [CpNi(bddt)] exhibits a blue shift compared with them. Interestingly, the absorption maximum of the butylene derivative [CpNi(bddt)] strongly differs from the propylene [CpNi(pddt)] (848 nm) or ethylene [CpNi(dddt)] (1012 nm in Table 4) derivatives (Chart 3).

This result clearly suggests that modifications of the outer substituents of the dithiolene core can modify the electronic absorption energy, even when the modification is limited to the substitution: ethylene vs. propylene vs. butylene. As already mentioned from the electrochemical results, this absorption energy blue shift is most probably related to the planarity and distortions of the outer substituents of the dithiolene core (see $\theta_{3}$ in Table 2).

\section{Solid-state structural and magnetic properties}

A projection view of the unit cell of the more flexible [CpNi(bddt)] complex is shown in Fig. 3 together with the shortest intermolecular S . S contacts identified in the structure. There are no other contacts along the third $a$ direction. This short S . S contact at $3.893 \AA$ is established between a sulfur atom of the metallacycle and a sulfur atom of the eightmembered ring. While a sizeable part of the spin distribution can be anticipated on the metallacycle sulfur atom, a weaker

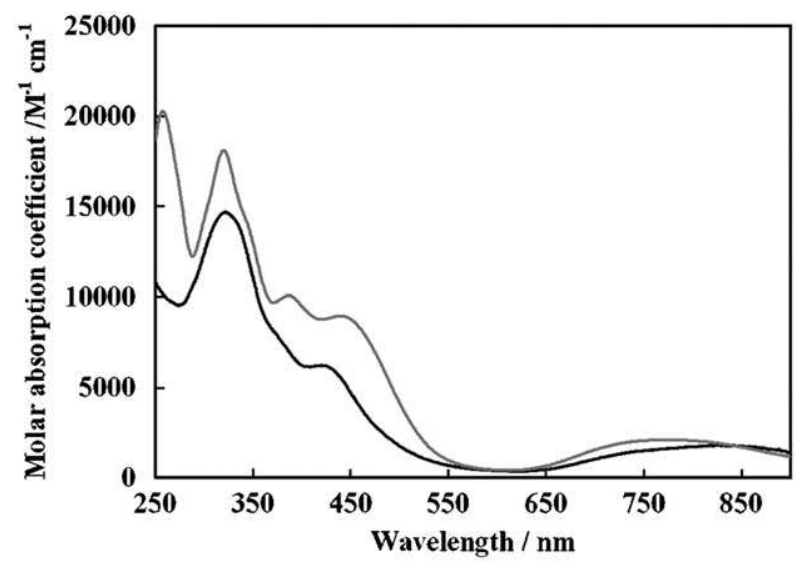

Fig. 2 UV-Vis-NIR spectra of [CpNi(oxddt)] (black line) and [CpNi(bddt)] (gray line) in dichloromethane solution. one probably characterizes the other one. As a consequence, a weak magnetic interaction is expected, which would develop, for symmetry reasons, into a regular one-dimensional spin chain.

The temperature dependence of the magnetic susceptibility of [CpNi(bddt)], determined from the SQUID measurement on a polycrystalline sample at $5000 \mathrm{G}$, indeed confirms this structural analysis (Fig. 4). The susceptibility exhibits a rounded maximum around $50 \mathrm{~K}$, demonstrating the presence of antiferromagnetic interactions, with only a weak decrease below $50 \mathrm{~K}$, excluding the possibility of a singlet ground state. A fit of the experimental data with the Bonner-Fisher model, ${ }^{22}$ taking into account a small contribution of magnetic defaults, observable at low temperatures, was used (eqn (1)):

$$
\chi_{\text {mol }}=\chi_{0}+x \chi_{\text {Curie }}+(1-x) \chi_{\mathrm{BF}}
$$

where $\chi_{0}$ is a temperature independent contribution, $x$ the fraction of paramagnetic defaults and $\chi_{\mathrm{BF}}$ the Bonner-Fischer susceptibility, expressed by a numerical expression ${ }^{23}$ depending on $J$ for the corresponding Hamiltonian (eqn (2)):

$$
H=-J \sum_{i=1}^{n-1} S_{i} S_{i+1} .
$$

Considering an averaged $g$ value ${ }^{15}$ of 2.05 for both the Curie tail and magnetic chain contributions, one obtains the following values from the fit: $\chi_{0}=3.00 \times 10^{-4} \mathrm{~cm}^{3} \mathrm{~mol}^{-1}$, $x=1.1 \%, J / k=-71.1(4) \mathrm{K}$, that is $J=-49 \mathrm{~cm}^{-1}$.

\begin{tabular}{|c|c|c|c|}
\hline & $\lambda_{\max } / \mathrm{nm}$ & $\varepsilon / \mathbf{M}^{-1} \mathrm{~cm}^{-1}$ & Ref. \\
\hline$[\mathrm{CpNi}(\mathrm{dddt})]$ & 1012 & 4700 & $15 c$ \\
\hline$[\mathrm{CpNi}(\mathrm{dmit})]$ & 967 & 6000 & $15 c$ \\
\hline$\left[\mathrm{CpNi}\left(\mathrm{S}_{2} \mathrm{C}_{2} \mathrm{Ph}_{2}\right)\right]$ & 846 & 2900 & $15 b$ \\
\hline$\left[\mathrm{CpNi}\left(\mathrm{S}_{2} \mathrm{C}_{2} \mathrm{Me}_{2}\right)\right]$ & 835 & 2600 & $15 b$ \\
\hline$\left[\mathrm{CpNi}\left(\mathrm{S}_{2} \mathrm{C}_{2} \mathrm{~S}_{2}\left(\mathrm{CH}_{2}\right)_{3}\right)\right]$ & 848 & 2100 & $15 d$ \\
\hline$\left[\mathrm{CpNi}\left(\mathrm{S}_{2} \mathrm{C}_{2} \mathrm{~S}_{2}\left(\mathrm{CH}_{2}\right)_{2}\left(\mathrm{C}=\mathrm{CH}_{2}\right)\right)\right]$ & 840 & 2400 & $15 d$ \\
\hline [CpNi(oxddt)] & 825 & 1900 & This work \\
\hline$\left[\mathrm{CpNi}\left(\mathrm{S}_{2} \mathrm{C}_{2} \mathrm{~S}_{2}\left(\mathrm{CH}_{2}\right)_{2}(\mathrm{~S})\right)\right]$ & 823 & 1800 & $15 d$ \\
\hline$\left[\mathrm{CpNi}\left(\mathrm{S}_{2} \mathrm{C}_{2} \mathrm{~S}_{2}\left(\mathrm{CH}_{2}\right)_{2}(\mathrm{C}=\mathrm{O})\right)\right]$ & 806 & 1700 & $15 d$ \\
\hline$\left[\mathrm{CpNi}\left(\mathrm{S}_{2} \mathrm{C}_{2} \mathrm{~S}_{2}\left(\mathrm{CH}_{2}\right)_{2}\left(\mathrm{CF}_{2}\right)\right)\right]$ & 798 & 2000 & $15 d$ \\
\hline [CpNi(bddt)] & 774 & 2100 & This work \\
\hline [CpNi(bdtodt)] & 741 & 6000 & $15 e$ \\
\hline$[\mathrm{CpNi}(\mathrm{bdt})]$ & 722 & 2600 & $15 c$ \\
\hline$[\mathrm{CpNi}(\mathrm{mnt})]$ & 698 & 2000 & $15 b$ \\
\hline$\left[\mathrm{CpNi}\left(\mathrm{S}_{2} \mathrm{C}_{2}\left(\mathrm{CO}_{2} \mathrm{Me}\right)_{2}\right)\right]$ & 695 & 1500 & $15 b$ \\
\hline
\end{tabular}

Table 4 UV-Vis-NIR data of all [CpNi(dithiolene)] complexes

All UV-Vis-NIR spectra were measured in dichloromethane solution. 
<smiles>c1cnn(N2SC3=C(SCCS3)S2)c1</smiles>

CpNi(dddt)<smiles>c1cc2n(n1)SC1=C(CCCS1)S2</smiles>

CpNi(pddt)

Chart 3

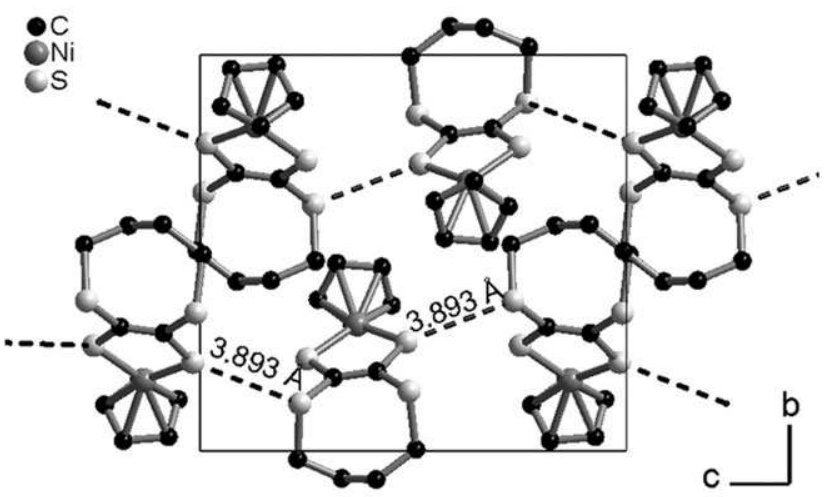

Fig. 3 Projection view along $a$ of the unit cell of [CpNi(bddt)] showing the uniform chain structure running along $c$.

As shown below in Fig. 5 and 6, the solid-state structure adopted with the more rigid $o$-xylylene derivative $[\mathrm{CpNi}($ oxddt $)]$ is very different. The molecules organize into inversion-centred dyads, weakly connected along the $a$ direction (Fig. 5) while a stronger overlap can be anticipated from the perfect, almost eclipsed, face-to-face overlap of the planar $\mathrm{C}_{2} \mathrm{~S}_{4}$ moieties within the dyads (Fig. 6). This structural "handmade" analysis is confirmed by the temperature dependence of the magnetic susceptibility. As shown in Fig. 4, it exhibits an acute maximum around $28 \mathrm{~K}$, together with a singlet ground state at the lowest temperatures and an activated susceptibility between these two regimes, a behaviour characteristic of the presence of a spin gap. Accordingly, a fit of the experimental

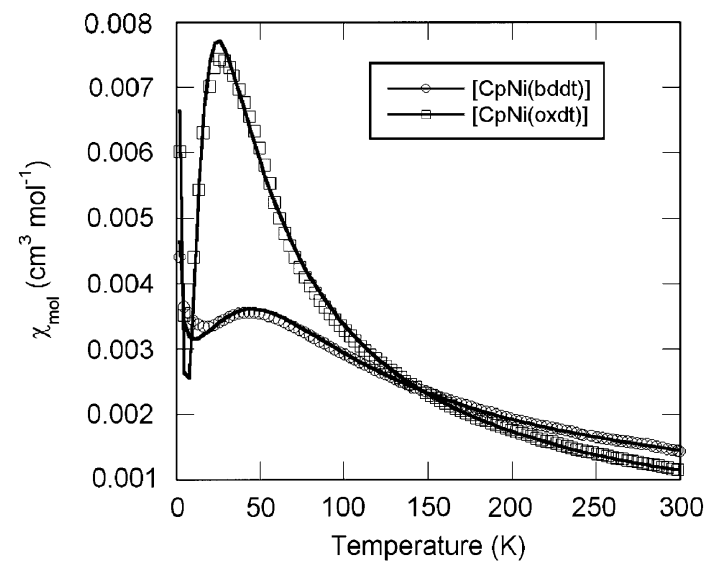

Fig. 4 Temperature dependence of the magnetic susceptibility of $[\mathrm{CpNi}(\mathrm{bddt})](\bigcirc)$ and $[\mathrm{CpNi}(\mathrm{oxddt})](\square)$. The solid lines are fits to the uniform Heisenberg spin chain model for [CpNi(bddt)] and to the singlet-triplet model for [CpNi(oxddt)] (see text).

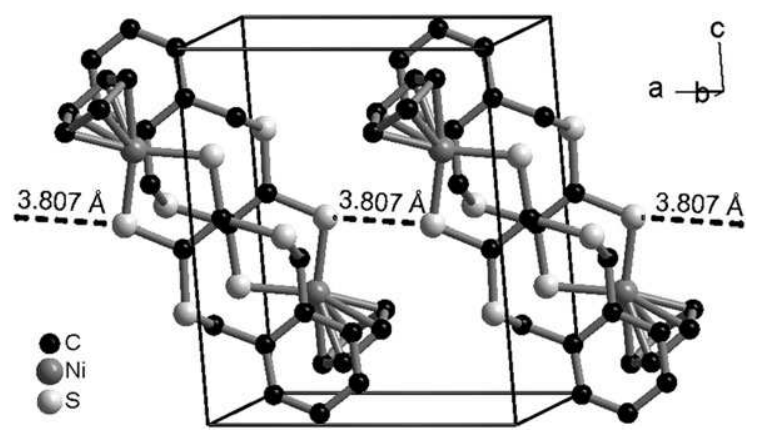

Fig. 5 A view of the short intermolecular $\mathrm{S} \cdots \mathrm{S}$ interactions running along the $a$ direction in [CpNi(oxddt)].

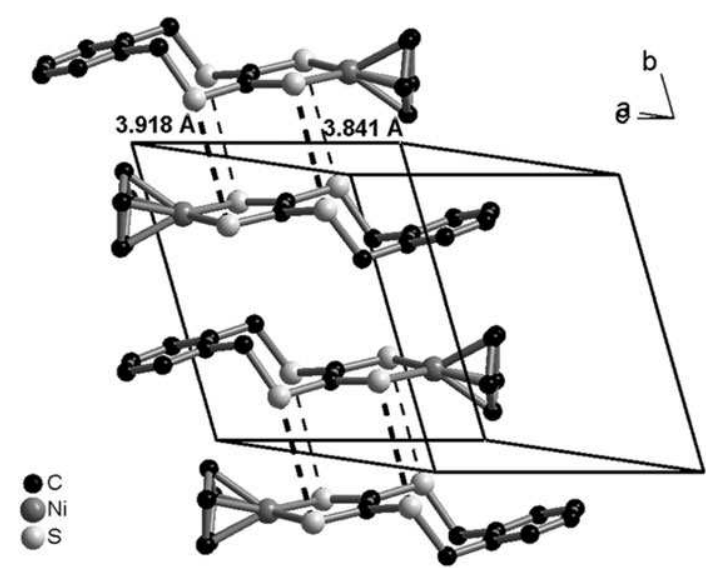

Fig. 6 A view of the stacking of [CpNi(oxddt)] radical complexes along the $b$ direction, showing the inversion-centred dyadic association.

data, expressed by eqn (3):

$$
\chi_{\text {mol }}=\chi_{0}+x \chi_{\text {Curie }}+(1-x) \frac{N \mathrm{~g}^{2} \beta^{2}}{k T[3+\exp (-J / k T)]},
$$

was performed with a $g$ value of 2.05 for both contributions, affording $\chi_{0}=-1.54 \times 10^{-4} \mathrm{~cm}^{3} \mathrm{~mol}^{-1}, x=3.4 \%$ and $J / k=$ $-41.7(4) \mathrm{K}$, that is $J=-29 \mathrm{~cm}^{-1}{ }^{24}$ The effectiveness of the singlet-triplet model to fit the magnetic susceptibility of [CpNi(oxddt)] also demonstrates that the localized magnetic interaction within the dyadic entities shown in Fig. 6 dominates the magnetic behaviour of the whole system. Considering the extra S $\cdots \mathrm{S}$ interaction running along $a$ and shown in Fig. 5, leads us to describe this material as a strongly alternated magnetic chain, with typically a similar temperature dependence of the magnetic susceptibility.

\section{Conclusions}

The two neutral radical organometallic complexes described here provide a striking example of the extreme sensitivity of the electronic and magnetic properties of such organometallic complexes to minor modifications of the substituents on the dithiolene core. Comparison of the two complexes with a similar fused eight-membered ring demonstrates how its rigidification in [CpNi(oxddt)] brought by the outer benzene ring 
completely modifies its packing in the solid state while the lower symmetry adopted by the butylene derivative [CpNi(bddt)] hinders the face-to-face dyadic association and thus favours an extended one-dimensional magnetic chain structure through lateral S...S interactions. Another impressive variability encountered in these series is found in their spectroscopic properties and specifically their NIR absorption energy. Comparison of the ethylene, propylene and butylene derivatives (Chart 3) shows a very large blue shift, from $1012 \mathrm{~nm}$ in $[\mathrm{CpNi}(\mathrm{dddt})]$ to $848 \mathrm{~nm}$ in $[\mathrm{CpNi}(\mathrm{pddt})]$ and $774 \mathrm{~nm}$ in [CpNi(bddt)]. This evolution correlates also with the increasing $E^{1 / 2}$ (vs. $\mathrm{Fc}^{+} / \mathrm{Fc}$ ) oxidation potentials, from $-0.02 \mathrm{~V}$ in $[\mathrm{CpNi}(\mathrm{dddt})]$ to $+0.07 \mathrm{~V}$ in $[\mathrm{CpNi}(\mathrm{pddt})]$ and $+0.14 \mathrm{~V}$ in [CpNi(bddt)]. Theoretical TD-DFT calculations will be performed in order to understand the origin of these NIR absorption bands and their evolution within these apparently simple series.

\section{Experimental}

\section{General remarks}

All reactions were carried out under an argon atmosphere by means of standard Schlenk techniques. All solvents for chemical reactions were dried and distilled by Na-benzophenone (for toluene) or $\mathrm{CaH}_{2}$ (for methanol) before use. The squareplanar nickel dithiolene complexes $\left[\mathrm{Ni}(\mathrm{oxddt})_{2}\right]^{25}$ and $\left(\mathrm{NBu}_{4}\right)$ $\left[\mathrm{Ni}(\mathrm{bddt})_{2}\right]^{20,26}$ were synthesized by literature methods. [CpNi $(\mathrm{cod})]\left(\mathrm{BF}_{4}\right)$ was prepared by a literature method. ${ }^{27}\left[\mathrm{Cp}_{2} \mathrm{Ni}\right]$ was obtained from STREM Chemicals and Aldrich Chemicals, respectively. Silica gel (Silica gel 60) was obtained from MERCK, Ltd. TOF-mass spectra were recorded on a Bruker Daltonics MALDI-TOF BIFLEX III mass spectrometer. UVVis and NIR spectra were recorded on a Hitachi Model UV2500PC and a Shimadzu Model UV-1605 spectrophotometer. Elemental analyses were performed by the "Service d'Analyse du CNRS" at Gif/Yvette, France.

\section{Preparation of [CpNi(oxddt)] from neutral starting materials [Ni(oxddt $\left.)_{2}\right]$ and $\left[\mathrm{Cp}_{2} \mathrm{Ni}\right]$}

A toluene solution of $\left[\mathrm{Cp}_{2} \mathrm{Ni}\right](53 \mathrm{mg}, 0.28 \mathrm{mmol})$ and [Ni(oxddt) $)_{2}(160 \mathrm{mg}, 0.28 \mathrm{mmol})$ was reacted under $80{ }^{\circ} \mathrm{C}$ for $2 \mathrm{~h}$. After the solvent was removed under reduced pressure, the residue was separated by column chromatography (silica gel, dichloromethane- $n$-hexane $=1: 1(\mathrm{v} / \mathrm{v}))$. The product was further purified by recrystallization ( $n$-hexane-dichloromethane) at room temperature. The $\mathrm{CpNi}$ dithiolene complex [CpNi(oxddt)] was obtained as black crystals in $44 \%$ yield. TOF-Mass (MALDI, $19 \mathrm{kV}) 379\left(\mathrm{M}^{+}\right), 275\left(\mathrm{M}^{+}-\right.$ $\left.\left(\mathrm{CH}_{2}\right)_{2} \mathrm{C}_{6} \mathrm{H}_{4}\right)$. UV-Vis $\left(\mathrm{CH}_{2} \mathrm{Cl}_{2}\right) \lambda_{\max } / \mathrm{nm}\left(\varepsilon / \mathrm{M}^{-1} \mathrm{~cm}^{-1}\right) 825$ (1900), 420 (6100), 321 (14000). Anal. Calc. for $\mathrm{C}_{15} \mathrm{H}_{13} \mathrm{NiS}_{4}$ : C, 47.38; H, 3.45; S, 33.73. Found: C, 47.44; H, 3.56; S, $33.89 \%$.

\section{Preparation of $[\mathrm{CpNi}(\mathrm{bddt})]$ from ionic starting materials $\left(\mathrm{NBu}_{4}\right)\left[\mathrm{Ni}(\text { bddt })_{2}\right]$ and $[\mathrm{CpNi}(\mathrm{cod})]\left(\mathrm{BF}_{4}\right)$}

A methanol solution of $[\mathrm{CpNi}(\mathrm{cod})]\left(\mathrm{BF}_{4}\right)(64 \mathrm{mg}, 0.2 \mathrm{mmol})$ and $\left(\mathrm{NBu}_{4}\right)\left[\mathrm{Ni}(\mathrm{bddt})_{2}\right](144 \mathrm{mg}, 0.2 \mathrm{mmol})$ was reacted under refluxing for $2 \mathrm{~h}$. After the solvent was removed under reduced pressure, the residue was separated by column chromatography (silica gel, dichloromethane- $n$-hexane $=2: 1(\mathrm{v} / \mathrm{v}))$. The product was further purified by recrystallization ( $n$-hexane-dichloromethane) at $0{ }^{\circ} \mathrm{C}$. [CpNi(bddt)] was obtained as black crystals in 30\% yield. TOF-Mass (MALDI, $19 \mathrm{kV}) 331\left(\mathrm{M}^{+}\right)$, $275\left(\mathrm{M}^{+}-\left(\mathrm{CH}_{2}\right)_{4}\right)$. UV-Vis $\left(\mathrm{CH}_{2} \mathrm{Cl}_{2}\right) \lambda_{\max } / \mathrm{nm}\left(\varepsilon / \mathrm{M}^{-1} \mathrm{~cm}^{-1}\right)$ 774 (2100), 439 (8800), 387 (9900), 320 (18000), 257 (20000). Anal. Calc. for $\mathrm{C}_{11} \mathrm{H}_{13} \mathrm{NiS}_{4}$ : C, 39.77; H, 3.94. Found: C, $39.68 ; \mathrm{H}, 3.67 \%$.

\section{X-Ray diffraction studies}

Single crystals of the $[\mathrm{CpNi}($ oxddt $)]$ and [CpNi(bddt)] complexes were obtained by recrystallization from dichloromethane solutions and then vapor diffusion of $n$-hexane into those solutions at $0{ }^{\circ} \mathrm{C}$. Crystals were mounted on the top of a thin glass fiber. Data were collected on a Stoe Imaging Plate Diffraction System (IPDS) with graphite-monochromated Mo-K $\alpha$ radiation $(\lambda=0.71073 \AA)$ at room temperature. Structures were solved by direct methods (SHELXS-97) and refined (SHELXL-97) ${ }^{28}$ by fill-matrix least-squares methods, as implemented in the WinGX software package. ${ }^{29}$ Absorption corrections were applied. Hydrogen atoms were introduced at calculated positions (riding model), included in structure factor calculations, and these were not refined. Crystallographic data for the complexes are summarized in Table 5.

CCDC reference numbers CCDC 630860 for [CpNi(bddt)] and 630861 for [CpNi(oxddt)].

For crystallographic data in CIF or other electronic format see DOI: $10.1039 / \mathrm{b} 700278 \mathrm{e}$

\section{CV measurements}

All electrochemical measurements were performed under an argon atmosphere. Solvents for electrochemical measurements

Table 5 Crystallographic data

\begin{tabular}{lll}
\hline Compound & {$[\mathrm{CpNi}($ oxddt $)]$} & {$[\mathrm{CpNi}(\mathrm{bddt})]$} \\
\hline Formula & $\mathrm{C}_{15} \mathrm{H}_{13} \mathrm{NiS}_{4}$ & $\mathrm{C}_{11} \mathrm{H}_{13} \mathrm{NiS}_{4}$ \\
$M_{\mathrm{r}}$ & 380.20 & 332.16 \\
Crystal color & $\mathrm{Black}$ & $\mathrm{Black}$ \\
Crystal size $/ \mathrm{mm}$ & $0.27 \times 0.21 \times 0.03$ & $0.18 \times 0.09 \times 0.09$ \\
Crystal system & Triclinic & Monoclinic \\
Space group & $P \overline{1}$ & $P 2_{1} / n$ \\
$a / \AA$ & $8.7690(10)$ & $8.5803(12)$ \\
$b / \AA$ & $9.3180(12)$ & $11.9991(15)$ \\
$c / \AA$ & $10.3604(15)$ & $12.9458(18)$ \\
$\alpha /{ }^{\circ}$ & $87.844(16)$ & \\
$\beta /{ }^{\circ}$ & $83.577(15)$ & $92.406(17)$ \\
$\gamma /{ }^{\circ}$ & $62.422(13)$ & \\
$V / \AA^{3}$ & $745.55(17)$ & $1331.7(3)$ \\
$T / \mathrm{K}$ & $293(2)$ & $293(2)$ \\
$Z$ & 2 & 4 \\
$D_{\mathrm{c}} / \mathrm{g}$ cm & & \\
$\mu /$ mm $^{-3}$ & 1.694 & 1.657 \\
Total refls. & 1.845 & 2.052 \\
Absorption correction & 7319 & 10111 \\
Unique refls. $\left(R_{\text {int }}\right)$ & $2714(0.0954)$ & Multi-scan \\
Unique refls. $(I>2 \sigma(I))$ & 1577 & $2413(0.1253)$ \\
$R_{1}, w R_{2}(I>2 \sigma(I))$ & $0.0752,0.2006$ & 1330 \\
$R_{1}, w R_{2}($ all data $)$ & $0.1208,0.2299$ & $0.0454,0.0744$ \\
Goodness-of-fit & 0.980 & 0.842 \\
$R_{1}=\sum \| F_{\mathrm{o}}|-| F_{\mathrm{c}}|| \sum\left|\sum F_{\mathrm{o}}\right| ; w R_{2}=\left[\sum w\left(F_{\mathrm{o}}{ }^{2}-F_{\mathrm{c}}{ }^{2}\right)^{2} / \sum w F_{\mathrm{o}}{ }^{4}\right]^{1 / 2}$. \\
\hline
\end{tabular}


were dried by $4 \AA$ A molecular sieves before use. A platinum wire served as a counter electrode, and the SCE (saturated calomel electrode) reference electrode was corrected for junction potentials by being referenced internally to the ferrocene/ferrocenium $\left(\mathrm{Fc} / \mathrm{Fc}^{+}\right)$couple. A stationary platinum disk $(1.0 \mathrm{~mm}$ in diameter) was used as the working electrode. $\mathrm{CV}$ measurements were performed with an Autolab PGSTAT 20 potentiostat from Eco Chemie B. V., equipped with General Purpose Electrochemical System GPES software (version 4.5 for Windows). Solution resistance was compensated by positive feedback. $1 \mathrm{mmol} \mathrm{dm}{ }^{-3}$ dichloromethane solutions of dithiolene complexes containing $0.1 \mathrm{~mol} \mathrm{dm}{ }^{-3}$ tetrabutylammonium hexafluorophosphate $\left(\mathrm{NBu}_{4} \mathrm{PF}_{6}\right)$ at $25{ }^{\circ} \mathrm{C}$ were used for measurements.

\section{Magnetic susceptibility measurements}

Magnetic susceptibility measurements were performed on a Quantum Design MPMS-2 SQUID magnetometer operating in the range of 2-300 $\mathrm{K}$ at $5000 \mathrm{G}$ with polycrystalline samples of [CpNi(oxddt)] $(4.5 \mathrm{mg})$ and [CpNi(bddt)] $(6.4 \mathrm{mg})$. Molar susceptibilities were corrected for Pascal diamagnetism.

\section{Acknowledgements}

We thank Professor Masatsugu Kajitani (Sophia University) for some UV-Vis-NIR and CV measurements. We also thank for the Ministère de la Recherche (France) and the ANR (France) (CHIRASYM project) for a post-doctoral grant (to M. N.).

\section{References}

1 (a) A. T. Coomber, D. Beljonne, R. H. Friend, J. L. Bredas, A. Charlton, N. Robertson, A. E. Underhill, M. Kurmoo and P. Day, Nature, 1996, 380, 144; (b) C. Faulmann and P. Cassoux, Prog. Inorg. Chem., 2003, 52, 399.

2 (a) P. Cassoux, L. Valade, H. Kobayashi, A. Kobayashi, R. A. Clark and A. E. Underhill, Coord. Chem. Rev., 1991, 110, 115; (b) R.-M. Olk, B. Olk, W. Dietzsch, R. Kirmse and E. Hoyer, Coord. Chem. Rev., 1992, 117, 99; (c) R. Kato, Chem. Rev., 2004, 104, 5319.

3 (a) S. D. Cummings and R. Eisenberg, Prog. Inorg. Chem., 2003, 52, 315; (b) H. Kisch, Coord. Chem. Rev., 1993, 125, 155.

4 (a) C. L. Beswick, J. M. Schulman and E. I. Stiefel, Prog. Inorg. Chem., 2003, 52, 55; (b) G. N. Schrauzer, Acc. Chem. Res., 1969, 2, 72 , and references therein.

5 (a) R. B. King, J. Organomet. Chem., 2001, 623, 95; (b) P. Falaras, C.-A. Mitsopoulou, D. Argyropoulos, E. Lyris, N. Psaroudakis, E. Vrachnou and D. Katakis, Inorg. Chem., 1995, 34, 4536; (c) R. Eisenberg, E. I. Stiefel, R. C. Rosenberg and H. B. Gray, J. Am. Chem. Soc., 1966, 88, 2874; (d) G. N. Schrauzer and V. P. Mayweg, J. Am. Chem. Soc., 1966, 88, 3235.

6 M. Roger, T. Arliguie, P. Thuery, M. Fourmigué and M. Ephritikhine, Inorg. Chem., 2005, 44, 584.

7 M. Roger, T. Arliguie, P. Thuery, M. Fourmigué and M. Ephritikhine, Inorg. Chem., 2005, 44, 594.

8 E. M. Weis, C. L. Barnes and P. B. Duval, Inorg. Chem., 2006, 45, 10126.

9 (a) W. Paw, S. D. Cummings, M. A. Mansour, W. B. Connick, B. K. Geiger and R. Eisenberg, Coord. Chem. Rev., 1998, 171, 125; (b) J. A. Zuleta, J. M. Bevilacqua and R. Eisenberg, Coord. Chem.
Rev., 1991, 111, 237; (c) J. A. Zuleta, M. S. Burberry and R. Eisenberg, Coord. Chem. Rev., 1990, 97, 47.

10 (a) M. Fourmigué, Coord. Chem. Rev., 1998, 178, 823; (b) A. Sugimori, T. Akiyama, M. Kajitani and T. Sugiyama, Bull. Chem. Soc. Jpn., 1999, 72, 879.

11 (a) K. Mashima, H. Kaneyoshi, S. Kaneko, K. Tani and A. Nakamura, Chem. Lett., 1997, 569; (b) K. Mashima, H. Kaneyoshi, S. Kaneko, A. Mikami, K. Tani and A. Nakamura, Organometallics, 1997, 16, 1016; (c) M. Nomura, M. Fujii, K. Fukuda, T. Sugiyama, Y. Yokoyama and M. Kajitani, J. Organomet. Chem., 2005, 690, 1627.

12 (a) E. J. Wharton, Inorg. Nucl. Chem. Lett., 1971, 7, 307; (b) K. Mashima, S. Kaneko and K. Tani, Chem. Lett., 1997, 347.

13 D. Sellmann, M. Geck, F. Knoch, G. Ritter and J. Dengler, J. Am. Chem. Soc., 1991, 113, 3819.

14 (a) R. Clérac, M. Fourmigué and C. Coulon, J. Solid State Chem., 2001, 159, 413; (b) R. Clérac, M. Fourmigué, J. Gaultier, Y. Barrans, P. A. Albouy and C. Coulon, Eur. Phys. J. B, 1999, 9, 445; (c) B. Domercq and M. Fourmigué, Eur. J. Inorg. Chem., 2001, 6, 1625; (d) M. Fourmigué, B. Domercq, I. V. Jourdain, P. Molinie, F. Guyon and J. Amaudrut, Chem. Eur. J., 1998, 4, 1714; (e) M. Fourmigué, C. Lenoir, C. Coulon, F. Guyon and J. Amaudrut, Inorg. Chem., 1995, 34, 4979; (f) J. K. Hsu, C. J. Bonangelino, S. P. Kaiwar, C. M. Boggs, J. C. Fettinger and R. S. Pilato, Inorg. Chem., 1996, 35, 4743.

15 (a) M. Fourmigué and N. Avarvari, Dalton Trans., 2005, 1365; (b) M. Nomura, R. Okuyama, C. Fujita-Takayama and M. Kajitani, Organometallics, 2005, 24, 5110; (c) M. Nomura, T. Cauchy, M. Geoffroy, P. Adkine and M. Fourmigué, Inorg. Chem., 2006, 45, 8194; (d) M. Nomura, M. Geoffroy, P. Adkine and M. Fourmigué, Eur. J. Inorg. Chem., 2006, 5012; (e) M. Nomura and M. Fourmigué, J. Organomet. Chem., 2007, DOI: 10.1016/j.jorganchem. 2007.02.030.

16 (a) K. Ray, T. Weyhermüller, F. Neese and K. Wieghardt, Inorg. Chem., 2005, 44, 5345; (b) B. Zhou, M. Shimamura, E. Fujiwara, A. Kobayashi, T. Higashi, E. Nishibori, M. Sakata, H. Cui, K. Takahashi and H. Kobayashi, J. Am. Chem. Soc., 2006, 128, 3872.

17 (a) M. Fourmigué and C. Coulon, Adv. Mater., 1994, 6, 948; (b) B. Domercq, C. Coulon, P. Feneyrou, V. Dentan, P. Robin and M. Fourmigué, Adv. Funct. Mater., 2002, 12, 359; (c) M. Nomura, S. Sakaki, C. Fujita-Takayama, Y. Hoshino and M. Kajitani, J. Organomet. Chem., 2006, 691, 3274.

18 (a) G. Matsubayashi, M. Nakano and H. Tamura, Coord. Chem. Rev., 2002, 226, 143; (b) H. Mori, M. Nakano, H. Tamura and G. Matsubayashi, J. Organomet. Chem., 1999, 574, 77; (c) H. Mori, M. Nakano, H. Tamura, G. Matsubayashi and W. Mori, Chem. Lett., 1998, 729.

19 C. Takayama, M. Kajitani, T. Sugiyama and A. Sugimori, $J$. Organomet. Chem., 1998, 563, 161.

20 R. D. Bereman, G. Chung, B. W. Knight, P. Singh and T. W. Welch, J. Coord. Chem., 1994, 32, 51.

21 (a) R. D. Bereman and H. Lu, Inorg. Chim. Acta, 1993, 204, 53; (b) O. J. Dautel and M. Fourmigué, Inorg. Chem., 2001, 40, 2083; (c) A. Charlton, A. E. Underhill, A. Kobayashi and H. Kobayashi, $J$. Chem. Soc., Dalton Trans., 1995, 1285; (d) R. Kato, H. Kobayashi, A. Kobayashi and Y. Sasaka, Bull. Chem. Soc. Jpn., 1986, 59, 627.

22 J. C. Bonner and M. E. Fisher, Phys. Rev. A, 1964, 135, 640.

23 O. Kahn, in Molecular Magnetism, VCH Weinheim, 1993, ch. 11.

24 The corresponding Hamiltonian can be written as: $H=-J S_{1} S_{2}$.

25 A. E. Underhill, B. Girmay and J. D. Kilburn, Synth. Met., 1993, 56, 1920.

26 G. Chung and R. D. Bereman, Bull. Korean Chem. Soc., 1996, 17, 612.

27 A. Salzer, T. L. Court and H. Werner, J. Organomet. Chem., 1973, 54, 325.

28 G. M. Sheldrick, SHELX97-Programs for Crystal Structure Analysis (Release 97-2), University of Göttingen, 1998.

29 L. J. Farrugia, J. Appl. Crystallogr., 1999, 32, 837. 